\title{
Removal of Phosphorus from LD Converter Slag by Floating Separation of Dicalcium Silicate during Solidification*
}

\author{
By Hitoshi ONO,** Akira INAGAKI,** Tamenori MASUI, ** Hiroshi NARITA, ** \\ Shoji NOSAKA,*** Toshiharu MITSUO**** and Susumu GOHDA ${ }^{* * * * *}$
}

\begin{abstract}
Synopsis
Mineralogical study of $L D$ converter slag was carried out by means of microscopic and EPMA examinations and phosphorus was found to exist only in dicalcium silicate as solid solution. This led to the study of separation of dicalcium silicate from $L D$ converter slag in order to remove phosphorus.

When liquid slag was solidified slowly, most dicalcium silicate particles accumulated in the top part of the crucible and fewer in the bottom. The phenomena can be interpreted as follows; on solidification, dicalcium silicate is crystallized primarily and floats up owing to the difference of density between dicalcium silicate and residual liquid. By using this phenomena, we can separate $L D$ converter slag into two layers, top and bottom in a vessel. As a result of slow cooling, $\mathrm{CaO}, \mathrm{SiO}_{2}$ and $\mathrm{P}_{2} \mathrm{O}_{5}$ are enriched in the top, and $\mathrm{FeO}, \mathrm{Fe}_{2} \mathrm{O}_{3}$ and $\mathrm{MnO}$ in the bottom.

Dicalcium silicate is apt to separate more efficiently with higher total iron content in slag, and at higher start temperature of cooling, close to liquidus temperature. The efficiency of separation was improved by blowing oxygen into the molten slag before cooling.
\end{abstract}

\section{Introduction}

As LD converter slag contains useful components, such as $\mathrm{FeO}, \mathrm{Fe}_{2} \mathrm{O}_{3}, \mathrm{MnO}, \mathrm{CaO}$ and $\mathrm{MgO}$, it can be economically recycled as an ironmaking material if removal of $\mathrm{P}_{2} \mathrm{O}_{5}$ is made possible. As Japan's requirements for phosphorus are entirely dependent upon imports, it is also important to use the Phosphorus enriched slag as a fertilizer.

For removal of $\mathrm{P}_{2} \mathrm{O}_{5}$ from $\mathrm{LD}$ converter slag, various methods have been attempted, including magnetic separation, ${ }^{1,2)}$ electrolytic dephosphorization, ${ }^{3,4)}$ floatation, ${ }^{5)}$ and dual-liquid phase separation methods. ${ }^{6}$ ) However, these methods involve some basic difficulties in practical application. Recently, Shiomi et al. ${ }^{7)}$ proposed a method in which phosphorus is removed through evaporation by adding silicon to the $\mathrm{Fe}-\mathrm{P}-\mathrm{C}$ alloy obtained as a result of reduction of the slag with carbon. However, this method has not been developed to the point where its practical application is assured.

Paying attention to the fact that $\mathrm{P}_{2} \mathrm{O}_{5}$ contained in LD converter slag is mostly crystallized in a solid solution form in the dicalcium silicate $\left(2 \mathrm{CaO} \cdot \mathrm{SiO}_{2}\right)$ phase during solidification, the authors have developed a method for removal of phosphorus by separating LD converter slag into two layers, i.e., top layer containing enriched phosphorus and bottom layer containing less phosphorus but rich in iron oxide, manganese oxide, etc., by utilizing the phenomenon in which dicalcium silicate is crystallized primarily during the cooling of slag and floats up owing to the difference of specific gravity between dicalcium silicate and residual liquid.

\section{Experimental Method}

1. Samples

The LD converter slags produced in a 170-t LD converter at Nippon Steel's Sakai Works under various blowing conditions were used for experiments. Samples were prepared by crushing $10 \mathrm{~kg}$ of lump slag to below $3 \mathrm{~mm}$, pulverizing to less than 100 mesh. Components, such as total $\mathrm{Fe}, \mathrm{CaO}, \mathrm{SiO}_{2}, \mathrm{MnO}$, $\mathrm{P}_{2} \mathrm{O}_{5}$ and $\mathrm{Al}_{2} \mathrm{O}_{3}$, were estimated by the method of fluorescent $\mathrm{X}$-ray analysis, while metallic iron, $\mathrm{FeO}$ and $\mathrm{Fe}_{2} \mathrm{O}_{3}$ were estimated by the chemical analysis. The compositions of samples used for experiments are given in Table 1 .

\section{Identification of Mineral Phases}

The mineral phases of LD converter slag were identified by microscopic and EPMA examinations. Samples for microscopic examination were prepared by buffing with diamond paste after polishing with sandpaper, while samples for EPMA examination were prepared by carbon evaporation. Microscopic observation was made by comparing the standard photographs $^{8)}$ of mineral phases which had been separately prepared using an optical microscope, a transmission microscope, X-ray diffraction equipment and EPMA. Standard samples of $\mathrm{Fe}, \mathrm{Mn}$,

Table 1. Chemical compositions of converter slag samples. (\%)

\begin{tabular}{r|cccccc}
\hline No. & T. Fe & $\mathrm{CaO}$ & $\mathrm{SiO}_{2}$ & $\mathrm{MnO}$ & $\mathrm{MgO}$ & $\mathrm{P}_{2} \mathrm{O}_{5}$ \\
\hline 1 & 17.0 & 48.3 & 12.2 & 6.8 & 5.8 & 2.61 \\
2 & 16.3 & 50.4 & 13.0 & 5.2 & 5.0 & 2.41 \\
3 & 12.3 & 49.6 & 16.8 & 4.9 & 5.4 & 2.32 \\
4 & 27.6 & 38.7 & 11.6 & 5.6 & 4.0 & 2.13 \\
5 & 25.1 & 41.1 & 11.7 & 5.6 & 5.8 & 1.89 \\
6 & 15.8 & 46.5 & 16.0 & 6.6 & 5.7 & 2.60 \\
7 & 15.7 & 50.8 & 13.9 & 5.5 & 4.2 & 2.29 \\
8 & 18.8 & 45.1 & 12.7 & 6.3 & 5.7 & 2.44 \\
9 & 24.7 & 39.5 & 10.2 & 5.7 & 3.4 & 1.65 \\
10 & 21.7 & 41.0 & 11.4 & 6.7 & 3.0 & 2.06 \\
11 & 21.6 & 41.6 & 15.5 & 5.9 & 3.9 & 2.18 \\
\hline
\end{tabular}

* Originally published in Tetsu-to-Hagané, 66 (1980), 1317, in Japanese. English version received April 18, 1980.

** Sakai Works, Nippon Steel Corporation, Chikko Yawata-cho, Sakai 590.

*** Yawata Works, Nippon Steel Corporation, Edamitsu, Yawatahigashi-ku, Kitakyushu 805

**** Products R \& D Laboratories, Nippon Steel Corporation, Fuchinobe, Sagamihara 229.

***** Process Technology R \& D Laboratories, Nippon Steel Corporation, Edamitsu, Yawatahigashi-ku, Kitakyushu 805. 
$\mathrm{Al}, \mathrm{Si}, \mathrm{Mg}, \mathrm{CaF}_{2}$ and InP were used for estimation by EPMA. For correction, absorption correction only was conducted, because this correction is considered to give the greatest effect.

\section{Method of Representation of Phase Diagram}

The composition of $\mathrm{LD}$ converter slag is represented by $\mathrm{CaO}, \mathrm{SiO}_{2}, \mathrm{FeO}, \mathrm{Fe}_{2} \mathrm{O}_{3}, \mathrm{MnO}, \mathrm{MgO}$ and $\mathrm{P}_{2} \mathrm{O}_{5}$. The slag composition was shown in the $(\mathrm{CaO}+\mathrm{MgO})^{\prime}-\left(\mathrm{SiO}_{2}+\mathrm{P}_{2} \mathrm{O}_{5}\right)^{\prime}-\left(\mathrm{FeO}+\mathrm{Fe}_{2} \mathrm{O}_{3}+\mathrm{MnO}\right)^{\prime}$ pseudo ternary system by grouping the components exhibiting similar behavior. And assuming the $\mathrm{CaO}-$ $\mathrm{SiO}_{2}-\mathrm{Fe}_{2} \mathrm{O}_{3}$ ternary system is realized in the pseudo ternary system, the liquidus temperature and boundary curves for the ternary system were shown in it as shown in Fig. 1. Hereinafter, $(\mathrm{CaO}+\mathrm{MgO})^{\prime},\left(\mathrm{SiO}_{2}\right.$ $\left.+\mathrm{P}_{2} \mathrm{O}_{5}\right)^{\prime}$ and $\left(\mathrm{FeO}+\mathrm{Fe}_{2} \mathrm{O}_{3}+\mathrm{MnO}\right)^{\prime}$ will be abbreviated as $\mathrm{CaO}_{\mathrm{t}}^{\prime}, \mathrm{SiO}_{2 \mathrm{t}}^{\prime}$ and $\mathrm{FeO}_{\mathrm{t}}^{\prime}$, respectively.

\section{Results and Discussion}

\section{Properties and Mineral Phases of LD Converter Slag}

\section{Properties of LD Converter Slag}

Slags of 57 heats dumped from the slag pan to the slag cooling yard and solidified thereat (hereinafter referred to as the "dumped slag") were collected at random for analysis of their compositions. As shown in Fig. 1, the compositions of most slags are in the primary crystal region of dicalcium silicate phase. However, the compositions of slags with low $\mathrm{FeO}_{t}(\%)$ and high $\mathrm{CaO}_{t} / \mathrm{SiO}_{2 \mathrm{t}}$ exist in the primary crystal region of tricalcium silicate $(3 \mathrm{CaO} \cdot \mathrm{SiO})$ phase or lime solid solution.

For phase separation of LD converter slag, the fluidity of liquid slag is considered to be an important factor. Accordingly, the fluidity of slag at $1500^{\circ}$ to $1600^{\circ} \mathrm{G}$ was examined. In practical operation, the fluidity of slag is evaluated, classifying slags into slag A (with good fluidity), slag B (with medium fluidity) and slag $\mathrm{C}$ (with poor fluidity) depending on the condition of its flow at the time of dumping from the slag pan into the cooling yard. In Fig. 1, the compositions of slags are shown together with their fluidity according to the above-mentioned classification. The effect of composition on fluidity is great. In particular, the composition is dominated by $\mathrm{FeO}_{\mathrm{t}}^{\prime}(\%)$. The viscosity of remelted slag measured by rotational cylinder method with $\mathrm{MgO}$ rotor and crucible in air is shown in Fig. 2. The viscosity of slag in the perfectly liquid state does not vary with the type of slag, but the temperature at which the viscosity starts to increase sharply due to crystallization varies considerably, suggesting a close correlation with fluidity. Visual observation revealed many unassimilated substances in slag $\mathrm{C}$ and fewer in slag B.

Based on these results, it may be said that the fluidity of slag at a constant temperature is related mainly to viscosity and is dependent upon liquidus temperature, the amount of suspended unassimilated particles, etc.

2. Mineral Phase of LD Converter Slag and Behavior of Phosphorus

The mineral phases constituting LD converter slag are dependent upon slag composition and the cooling rate during solidification. As the present research aims at the phase separation of LD converter slag, study was made on the identification of the compositions of mineral phases crystallized under the slow cooling condition and the distribution of phosphorus to each phase.

The kinds of mineral phases observed in slag and the results determined by EPMA examination are given in Table 2. The phases observed in large quantities in all slags are dicalcium silicate, dicalcium ferrite titanate solid solution $\left(\mathrm{Ca}_{2}(\mathrm{Al}, \mathrm{Fe})_{2} \mathrm{O}_{5}-\mathrm{Ca}\right.$ $\left.(\mathrm{Si}, \mathrm{Ti}) \mathrm{O}_{3}\right)$ and magnesio wüstit $((\mathrm{Mg}, \mathrm{Fe}) \mathrm{O})$. Figure 3 shows the results of line scanning of slags of typical compositions by EPMA. It is apparent that phosphorus exists in the dicalcium silicate phase. The

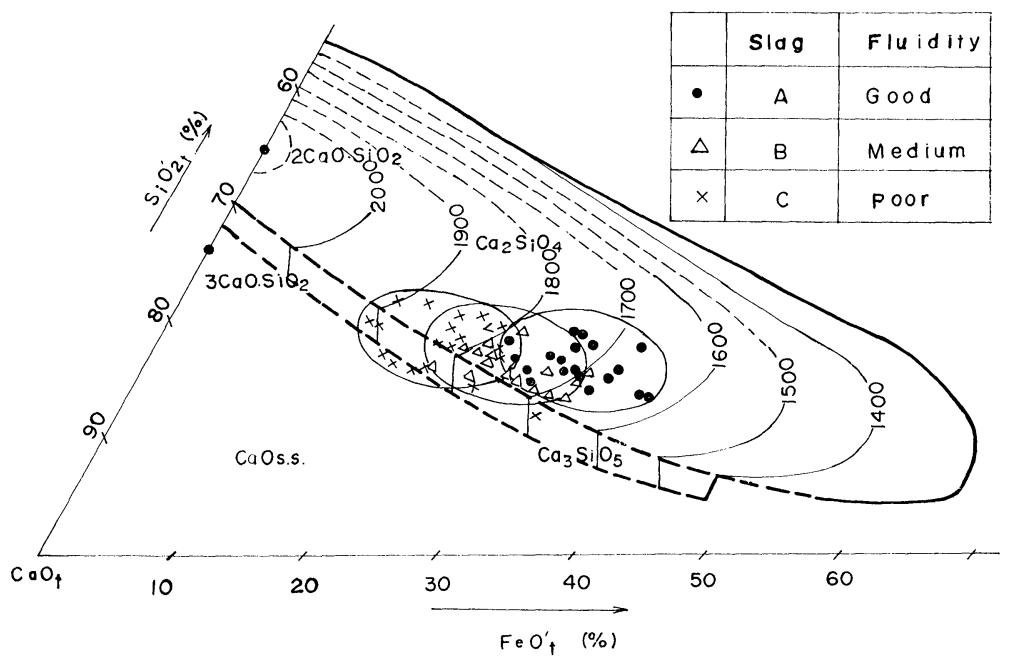

Fig. 1. Relation between converter slag composition and fluidity of liquid slag at about $1550^{\circ} \mathrm{C}$ in $\mathrm{CaO}_{\mathrm{t}}^{\prime}-\mathrm{SiO}_{2 \mathrm{t}}^{\prime}-\mathrm{FeO}_{\mathrm{t}}^{\prime}$ quasi-ternary phase diagram. Liquidus lines and boundary curves shown in this diagram are for the $\mathrm{CaO}-\mathrm{SiO}_{2}-\mathrm{Fe}_{2} \mathrm{O}_{3}$ system. ${ }^{\text {) }}$

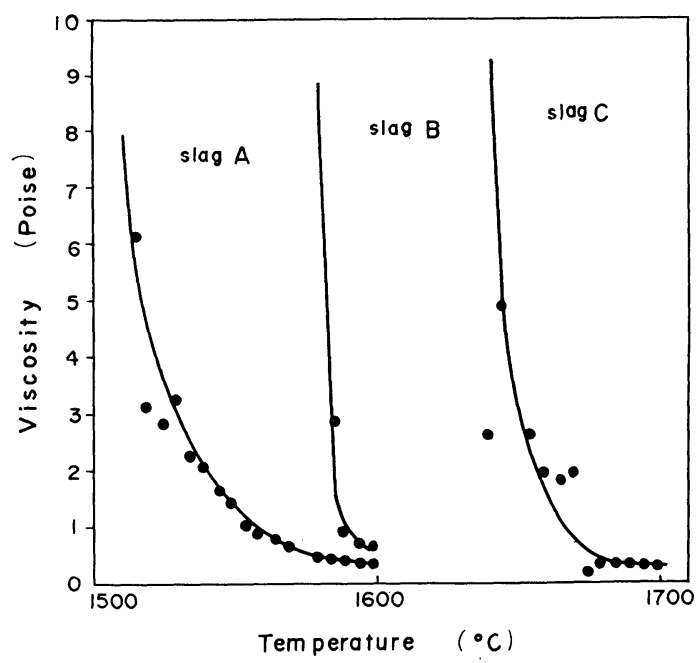

Fig. 2. Relation between temperature and viscosity of liquid converter slags of various fluidities. A, $\mathrm{B}$ and $\mathrm{C}$ slags correspond to sample numbers 1, 2 and 3, respectively, in Table 1. 
existence of phosphorus in this phase has already been reported by Suito et $a ._{.}{ }^{2)}$ and Narita et al. ${ }^{10)}$ As shown in Table 2, the tricalcium silicate and lime solid solution (lime s.s.) phases also contain $\mathrm{P}_{2} \mathrm{O}_{5}$. But as these phases appear in a specific range of composition, they can be neglected. Thus, it may be said that the whole quantity of $\mathrm{P}_{2} \mathrm{O}_{5}$ is distributed in the dicalcium silicate phase.

The solid solubility limit of $\mathrm{P}_{2} \mathrm{O}_{5}$ in the dicalcium silicate phase differs from researcher to researcher. According to, for example, the phase diagram proposed by Nurse et al., ${ }^{11)} \mathrm{Ca}_{2} \mathrm{SiO}_{4}$ and $\mathrm{Ca}_{3} \mathrm{P}_{2} \mathrm{O}_{3}$ are completely miscible. For the solid solubility of $\mathrm{P}_{2} \mathrm{O}_{5}$, however, many researchers reported different values; approximately $10 \%$ by Barrett and McCaughey, ${ }^{12)}$ about $3 \%$ by Trömel, ${ }^{13)} 2.8 \%$ by Narita et al., and 1.0 to $1.5 \%$ by Zerfoss and Davis. ${ }^{14)}$

Against this background, the solid solubility of $\mathrm{P}_{2} \mathrm{O}_{5}$ in the dicalcium silicate phase was studied using the $\mathrm{SiO}_{2}$ balance. Generally, LD converter slag with good fluidity has three main phases; dicalcium silicate, dicalcium ferrite titanate s.s. and magnesio wüstit. The ratio of other phases is very small. The amount of $\mathrm{SiO}_{2}$ contained in the dicalcium ferrite titanate s.s. and magnesio wüstit phases is also very small. If $\mathrm{SiO}_{2}$ in these phases is neglected, it may be said that the whole quantity of $\mathrm{SiO}_{2}$ contained in the slag will exist in the dicalcium silicate phase. Furthermore, assume that the whole quantity of $\mathrm{P}_{2} \mathrm{O}_{5}$ exists in a solid solution form in the dicalcium silicate phase, forming $3 \mathrm{CaO} \cdot \mathrm{P}_{2} \mathrm{O}_{5}$ as shown in the $\mathrm{Ca}_{2} \mathrm{SiO}_{4}-\mathrm{Ca}_{3} \mathrm{P}_{2} \mathrm{O}_{8}$ phase diagram proposed by Nurse et al., then, the amount of dicalcium silicate phase and $\mathrm{P}_{2} \mathrm{O}_{5}(\%)$ in the dicalcium silicate phase can be calculated as follows:

$$
\begin{gathered}
\% \mathrm{C}_{2} \mathrm{~S}_{\mathrm{s.s.}}=\% \mathrm{C}_{2} \mathrm{~S}+\% \mathrm{C}_{3} \mathrm{P} \ldots \\
\% \mathrm{C}_{2} \mathrm{~S}=(172 / 60) \times \% \mathrm{SiO}_{2} \\
\% \mathrm{C}_{3} \mathrm{P}=(310 / 142) \times \% \mathrm{P}_{2} \mathrm{O}_{5} \\
\% \mathrm{P}_{2} \mathrm{O}_{5}^{\prime} \text { cal. }=\frac{\% \mathrm{P}_{2} \mathrm{O}_{5}}{\% \mathrm{C}_{2} \mathrm{~S}_{\text {s.s. }}} \times 100
\end{gathered}
$$

where $\mathrm{C}_{2} \mathrm{~S}$ is dicalcium silicate, $\mathrm{C}_{3} \mathrm{P}$ is tricalcium phosphate $\left(3 \mathrm{CaO} \cdot \mathrm{P}_{2} \mathrm{O}_{5}\right)$, and $\mathrm{C}_{2} \mathrm{~S}_{\mathrm{s} \text {.s. }}$ is a solid solution of dicalcium silicate and tricalcium phosphate. $\% \mathrm{SiO}_{2}$ and $\% \mathrm{P}_{2} \mathrm{O}_{5}$ indicate their contents in the mother slag, while $\% \mathrm{P}_{2} \mathrm{O}_{5}^{\prime}$ cal. is the calculated value of $\mathrm{P}_{2} \mathrm{O}_{5}(\%)$ in the dicalcium silicate phase determined by Eq. (4).

For LD converter slag and the slag remelted after addition of $\mathrm{P}_{2} \mathrm{O}_{5}$, study was made on the relation between $\% \mathrm{P}_{2} \mathrm{O}_{5}^{\prime}$ cal. and $\% \mathrm{P}_{2} \mathrm{O}_{5}^{\prime}$ anal. in the dicalcium silicate phase which was determined by EPMA. As shown in Fig. 4, a relation of nearly 1 to 1 was ob-

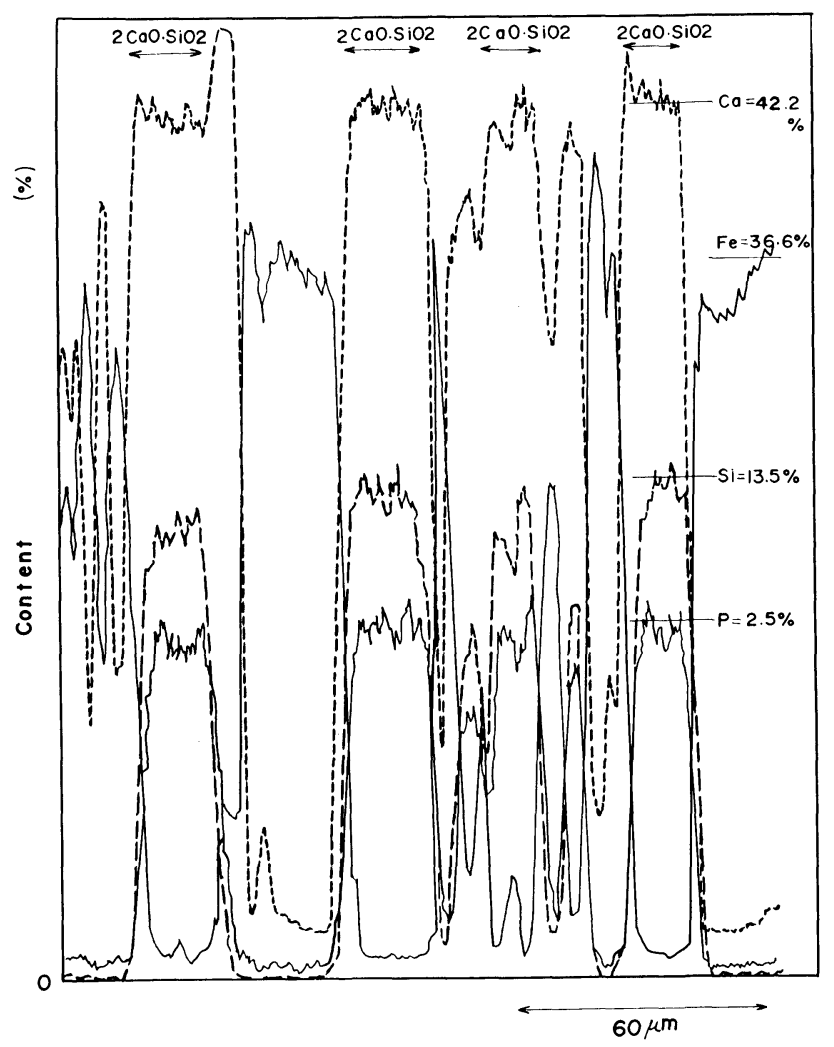

Fig. 3. Results of line scanning of slags of typical composi-

\begin{tabular}{|c|c|c|c|c|c|c|c|c|c|c|}
\hline \multirow{2}{*}{ Mineral phase } & \multirow{2}{*}{$\begin{array}{l}\text { Slag } \\
\text { No. }\end{array}$} & \multicolumn{9}{|c|}{ Composition (wt.\%) } \\
\hline & & $\mathrm{CaO}$ & $\mathrm{SiO}_{2}$ & $\begin{array}{c}\mathrm{FeO} \\
\left(\mathrm{Fe}_{2} \mathrm{O}_{3}\right)\end{array}$ & $\mathrm{MnO}$ & $\mathrm{MgO}$ & $\mathrm{P}_{2} \mathrm{O}_{5}$ & $\mathrm{Al}_{2} \mathrm{O}_{3}$ & $\mathrm{TiO}_{2}$ & $\mathrm{Cr}_{2} \mathrm{O}_{3}$ \\
\hline \multirow{3}{*}{ Dicalcium silicate } & 4 & 58.00 & 33.84 & 0.54 & - & 0.01 & 3.62 & 0.67 & 0.50 & 0.04 \\
\hline & 5 & 60.62 & 28.98 & 1.13 & 0.06 & 0.63 & 4.36 & - & - & - \\
\hline & 6 & 59.59 & 33.15 & 0.56 & 0.10 & 0.05 & 5.49 & - & - & - \\
\hline Tricalcium silicate & 7 & 68.20 & 25.70 & 2.15 & 1.55 & 0.08 & 1.10 & 0.30 & 0.37 & - \\
\hline Dicalcium ferrite & 4 & 49.64 & 1.48 & $(48.11)$ & 0.36 & 4.24 & 0.02 & - & - & - \\
\hline Dicalcium ferrite titanate s.s. & 4 & 52.70 & 2.55 & $(33.31)$ & 0.88 & 0.43 & 0.32 & 3.25 & 8.53 & 0.39 \\
\hline \multirow{2}{*}{ Magnesio wüstit } & 4 & 2.12 & 2.08 & 61.80 & 17.50 & 5.68 & - & - & - & - \\
\hline & 8 & 3.20 & 0.05 & 46.80 & 12.10 & 38.10 & - & - & - & 一 \\
\hline Lime s.s. $\left(\mathbf{L}_{2}\right)$ & 7 & 73.00 & 0.05 & 10.10 & 10.80 & 2.80 & 0.35 & 一 & - & 一 \\
\hline$» \quad\left(\mathrm{~L}_{1}\right)$ & 4 & 100.5 & 一 & 一 & - & - & - & 一 & 一 & 一 \\
\hline
\end{tabular}
tions by EPMA. Phosphorus was generally observed in the dicalcium silicate phase.

Table 2. Compositions of several phases in converter slag determined by EPMA. 
tained. It is, therefore, considered that the whole quantity of $\mathrm{P}_{2} \mathrm{O}_{5}$ in slag exists as solid solution in the dicalcium silicate phase. In the normal operation, the $\mathrm{P}_{2} \mathrm{O}_{5}$ content of slag is as low as 1 to $3 \%$, and therefore the $\mathrm{P}_{2} \mathrm{O}_{5}$ concentration in the dicalcium silicate phase is no more than $6 \%$. However, further enrichment of $\mathrm{P}_{2} \mathrm{O}_{5}$ in the dicalcium silicate phase will be possible. As shown in Fig. 4, it was confirmed that concentrations of $\mathrm{P}_{2} \mathrm{O}_{5}$ in excess of $30 \%$ are possible depending on $\mathrm{P}_{2} \mathrm{O}_{5}$ content of the slag or changes in the amount of $\mathrm{C}_{2} \mathrm{~S}_{\text {s.s. }}$ As is apparent from the phase diagram proposed by Nurse et al., it is considered that the solid solution of dicalcium silicate and tricalcium phosphate are transformed into various phases at low temperatures but $2 \mathrm{CaO} \cdot \mathrm{SiO}_{2}-$ $3 \mathrm{CaO} \cdot \mathrm{P}_{2} \mathrm{O}_{5}$ forms a uniform solid solution at temperatures above $1300^{\circ} \mathrm{C}$ at which the separation of dicalcium silicate is made possible. Accordingly, removal of phosphorus from $L D$ converter slag is made possible by adjusting the slag composition so as to enter the primary crystal region of dicalcium silicate phase and by separating the dicalcium silicate phase which is crystallized in the course of solidification.

\section{Separation of LD Converter Slag into Two Layers and Conditions for Removal of Phosphorus}

\section{Separation of LD Converter Slag into Two Layers}

A magnesia crucible $(53 \mathrm{~mm} \phi \times 95 \mathrm{~mm})$ containing $300 \mathrm{~g}$ of slag (No. 9) crushed to less than 100 mesh was placed in a box type siliconcarbide resistance furnace for complete remelting in air. After that, the liquid slag was slowly cooled in the furnace from $1600^{\circ} \mathrm{C}$ to about solidus temperature. The longitudinal cross-section of the sample was polished, as a result of which the macrostructure as shown in Photo. 1 was obtained. As shown in this photograph, the slag was separated into two layers, top and bottom, in the crucible. To clarify the separating condition, microscopic observation was made, the results of which are shown in Photo. 2. Many coarsened dicalcium silicate particles are present in the

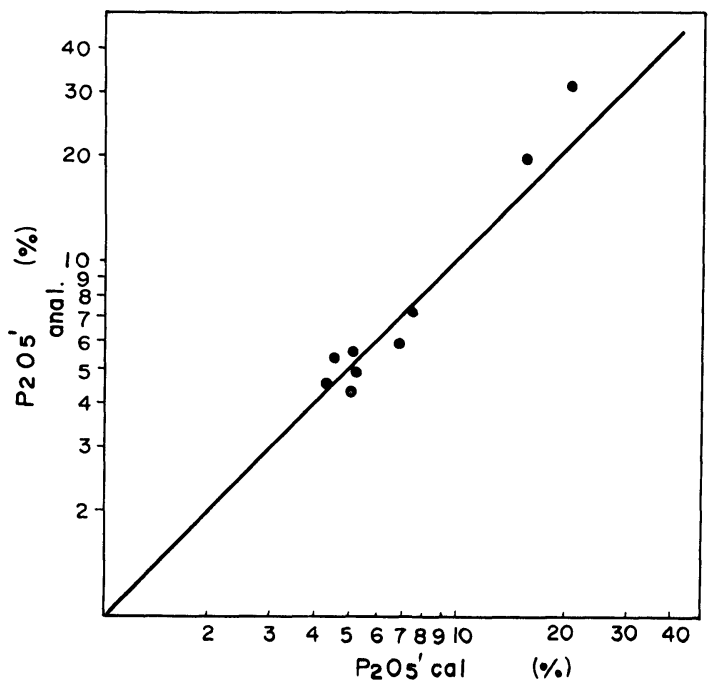

Fig. 4. Comparison of calculated and measured $\mathrm{P}_{2} \mathrm{O}_{5}$ contents in the solid solution of dicalcium silicate. top layer but considerably fewer are present in the bottom layer. Table 3 gives the results of analysis of the composition of each layer in the same sample. It was found that $\mathrm{SiO}_{2}$ and $\mathrm{P}_{2} \mathrm{O}_{5}$ are enriched in the top layer but $\mathrm{T}$. Fe and $\mathrm{MnO}$ are enriched and $\mathrm{P}_{2} \mathrm{O}_{5}$ decreases in the bottom layer.

The above-mentioned results can be interpreted as follows. The dicalcium silicate particles which were primarily crystallized and grew during the cooling of liquid slag are separated and float up owing to the difference of specific gravity between dicalcium

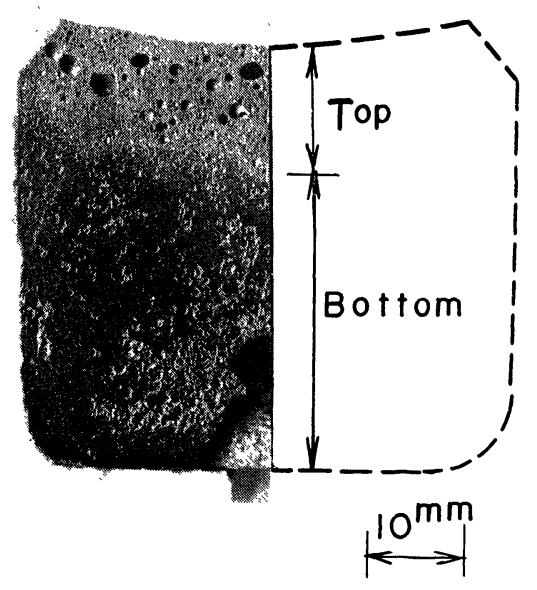

Photo. 1. Macrostructure of slag slowly cooled in a crucible. Dicalcium silicate is enriched in the top (light gray region) but not in the bottom (dark gray region).

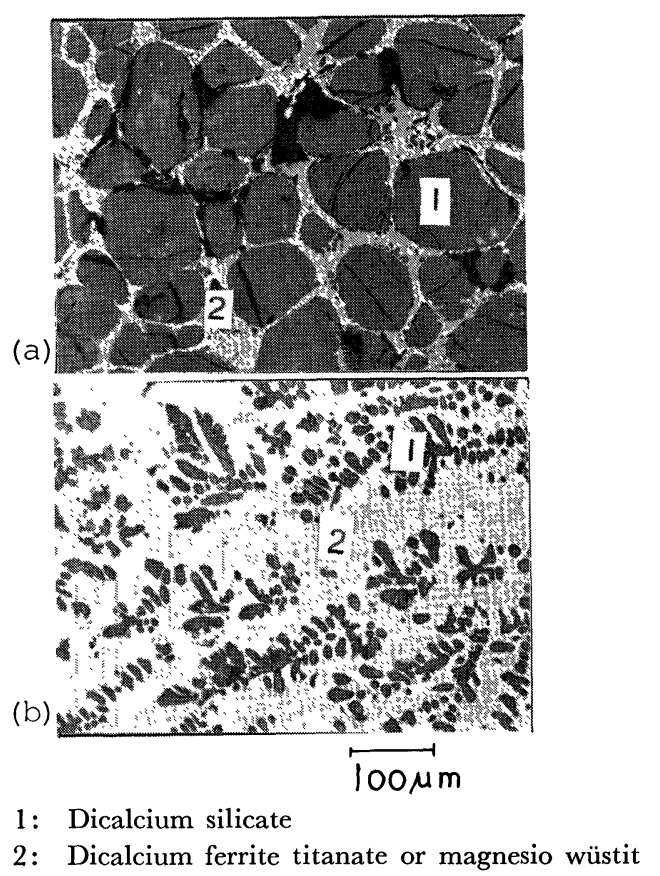

Photo. 2. Microstructure of slag slowly cooled in a crucible (a) top, (b) bottom.

Table 3. Compositions of top and bottom layers of slag.

\begin{tabular}{l|rrrrrr}
\hline & $\mathrm{T} . \mathrm{Fe}$ & $\mathrm{CaO}$ & $\mathrm{SiO}_{2}$ & $\mathrm{MnO}$ & $\mathrm{MgO}$ & $\mathrm{P}_{2} \mathrm{O}_{5}$ \\
\hline Top & 14.0 & 47.6 & 18.5 & 3.0 & 4.1 & 3.14 \\
\hline Bottom & 29.2 & 34.9 & 7.1 & 5.9 & 5.6 & 0.96 \\
\hline
\end{tabular}


silicate and residual liquid. Although the ratio of top layer to bottom was 30 to 70 in the present experiment, it is considered that separation was done effectively because of high $\mathrm{FeO}_{\mathrm{t}}(\%)$ of the slag used and smaller height of the crucible employed.

In the next experiment, slag obtained from actual operation was cast into an upright cylindrical mold made of steel plate $(1200 \mathrm{~mm} \phi \times 1800 \mathrm{~mm})$. Figure 5 shows the distribution of $\mathrm{P}_{2} \mathrm{O}_{5}$ in slag A (No. 4) of good fluidity, in the height direction at a point $300 \mathrm{~mm}$ inside from the surface of slag ingot. Like the results obtained from experiment in a crucible, the amount of $\mathrm{P}_{2} \mathrm{O}_{5}$ was very small at the ingot bottom, evidencing good separation. In this experiment, the ratio of top layer to bottom was generally 60 to 40 . This may be because the floating distance of dicalcium silicate was longer as compared with that in the experiment in a crucible.

\section{Conditions for Removal of Phosphorus from LD}

\section{Converter Slag}

It is considered that the separation of dicalcium silicate phase proceeds under the mutual influence of the conditions for crystallization and floating separation of particles. To improve the efficiency of separation, therefore, studies should be made on the physical properties of slag, such as the difference of density between dicalcium silicate particles and residual liquid and the viscosity of liquid slag, as well as operating conditions, such as slag composition, temperature and cooling rate. In this paragraph, the operating conditions are described. Evaluation was made by defining Eqs. (5) and (6) based on the analytical values of bottom layer sample obtained from a position on the central axis $20 \%$ up from the ingot bottom and of average sample of bottom layer $(40 \%)$ as characteristic values indicating the separability of $\mathrm{P}_{2} \mathrm{O}_{5}$.

$$
\begin{aligned}
& \mathrm{SR}_{(\mathrm{I})}=\frac{\% \mathrm{P}_{2} \mathrm{O}_{5}-\% \mathrm{P}_{2} \mathrm{O}_{5}(\mathrm{~L})}{\% \mathrm{P}_{2} \mathrm{O}_{5}} \times 100(\%) \\
& \mathrm{SR}_{(\mathrm{II})}=\frac{\% \mathrm{P}_{2} \mathrm{O}_{5}-\% \mathrm{P}_{2} \mathrm{O}_{5}(\overline{\mathrm{L}})}{\% \mathrm{P}_{2} \mathrm{O}_{5}} \times 100(\%) \quad \ldots . .(5)
\end{aligned}
$$

where $\% \mathrm{P}_{2} \mathrm{O}_{5}(\mathrm{~L})$ and $\% \mathrm{P}_{2} \mathrm{O}_{5}(\overline{\mathrm{L}})$ indicate the analytical values of the sample obtained from a position of $20 \%$ up from the ingot bottom and of average sample of bottom layer $(40 \%)$, respectively. $\mathrm{SR}_{(\mathrm{I})}$ and $\mathrm{SR}_{(\mathrm{II})}$ are the separating ratios of $\mathrm{P}_{2} \mathrm{O}_{5}$, respectively, and $\% \mathrm{P}_{2} \mathrm{O}_{5}$ indicates $\mathrm{P}_{2} \mathrm{O}_{5} \%$ in the slag.

\section{(1) Effect of Composition}

To remove phosphorus utilizing the floating separation of dicalcium silicate particles, it is necessary to adjust the composition of slag to the primary crystal region of dicalcium silicate phase. Based on the results of study of mineral phases, the primary crystal of LD converter slag is roughly divided into the following three cases.

(a) This is the case in which dicalcium silicate is primary crystal. As shown in Fig. 1, slags obtained from actual operation belong to this composition range.

(b) This is the case in which $\mathrm{FeO}_{t}$ is low but $\left(\mathrm{CaO}_{\mathrm{t}} / \mathrm{SiO}_{2 \mathrm{t}}\right)$ is high. In the slag belonging to slag

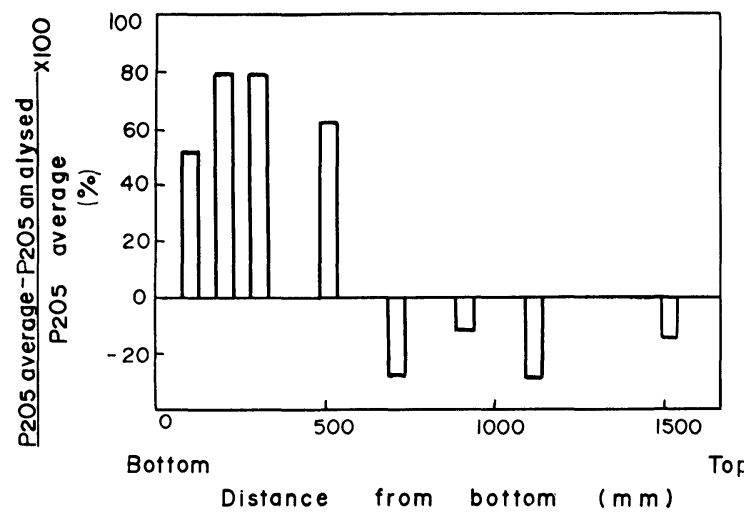

Fig. 5. Separation ratio of $\mathrm{P}_{2} \mathrm{O}_{5}$ in slowly cooled slag ingot at a point $300 \mathrm{~mm}$ from the surface. Ingot size was $1200 \mathrm{~mm}$ in diameter and $1800 \mathrm{~mm}$ in height.

$\mathrm{C}$ as shown in Fig. 1, lime s.s. or tricalcium silicate are observed in large quantities. This slag is not suitable for separation because of inferior fluidity. Because of large quantities of suspended iron drops, however, its composition can be changed to the primary crystal region of dicalcium silicate phase by blowing oxygen into the slag.

(c) When high-dolomite operation is conducted to prolong the lining life of LD converter, magnesio wüstit is crystallized as primary crystal because $\mathrm{MgO}(\%)$ becomes high. As a result of cooling test conducted in an $800 \mathrm{~mm} \phi$ cylindrical mold, it was found that $\mathrm{SR}_{(\mathrm{I})}$ decreases with increasing $\mathrm{MgO}(\%)$. When the $\mathrm{MgO}$ content is below 8\%, however, its effect is small.

In all of the cases described above, it is possible to select and adjust the composition of slag so that it enters the primary crystal region of dicalcium silicate phase. As described later, it is desirable to start slow cooling from a temperature higher than the temperature at which the crystallization of dicalcium silicate phase is started. If the temperature condition in actual operation is taken into consideration, therefore, the slag composition with low melting point is desirable.

(2) Effect of Starting Temperature of Crystallization

Samples were prepared by reheating slags in crucibles, holding for $30 \mathrm{~min}$ at specified different test temperatures while agitating, and then quenching. Observing the samples under a microscope, the liquidus temperature at which undissolved particles disappear was determined. Then, the slag with a liquidus temperature of $1550^{\circ} \mathrm{G}$ (No. 10) was completely dissolved in a crucible, cooled at a rate of $100^{\circ} \mathrm{G} / \mathrm{hr}$ with quenching from various test temperatures during cooling. As a fine crystal structure was obtained when quenching was started from a temperature above $1450^{\circ} \mathrm{C}$, the slag before quenching must have been in the liquid phase. The grain size increased abruptly when the starting temperature of quenching was below $1450^{\circ} \mathrm{C}$, and therefore this temperature is considered to be the temperature at which the crystallization of dicalcium silicate is started. When the cooling rate is $100^{\circ} \mathrm{C} / \mathrm{hr}$, therefore, the difference 
between liquidus temperature and starting temperature of crystallization (supercooling) will be about $100^{\circ} \mathrm{C}$. On the other hand, liquidus temperature of slags were measured by the above-mentioned method. And it was confirmed that the measured liquidus temperature was about $50^{\circ}$ to $100^{\circ} \mathrm{C}$ lower than that determined from Fig. 1. If the difference between the liquidus temperature determined from Fig. 1 and the measured value and the degree of supercooling are applicable to all slag compositions, the starting temperature of crystallization of slag A is about $1550^{\circ} \mathrm{C}$ because its liquidus temperature is about $1700^{\circ} \mathrm{G}$ according to Fig. 1. Accordingly, the starting temperature of crystallization will drop depending on the degree of temperature drop during handling until the cooling of liquid slag in the mold is started. If slow cooling is done at a very low cooling rate, however, this difference in temperature is expected to be smaller.

Figure 6 shows the results of bottom layer sampling test conducted during the solidification of slag in the mold made of steel plate. It will be seen that the separation ratio of $\mathrm{P}_{2} \mathrm{O}_{5}$ is high when the starting temperature of cooling is high.

(3) Effect of Cooling Rate

Judging from Stokes' equation, the floating speed

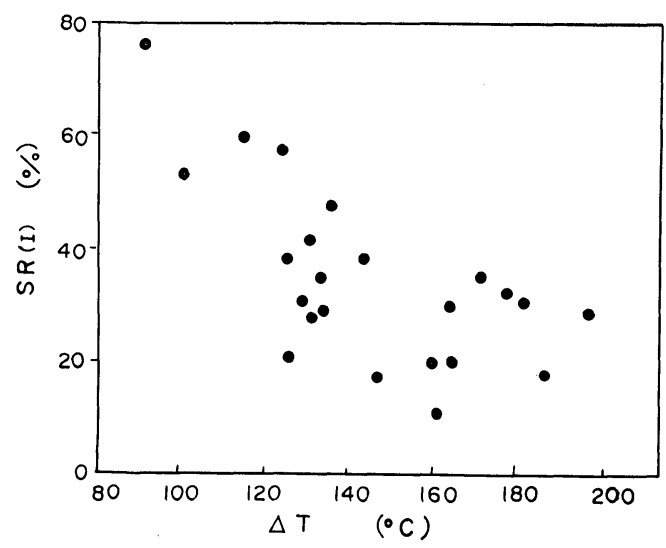

$\Delta T=$ Liquidus temp. - Start temp. of cooling

$$
\mathrm{SR}_{(\mathrm{I})}=\frac{\% \mathrm{P}_{2} \mathrm{O}_{5} \text { (av.) }-\% \mathrm{P}_{2} \mathrm{O}_{5} \text { (Bottom) }}{\% \mathrm{P}_{2} \mathrm{O}_{5} \text { (av.) }} \times 100(\%)
$$

Fig. 6. Relation between $\Delta T$ and the separation ratio of $\mathrm{P}_{2} \mathrm{O}_{5}\left(\mathrm{SR}_{(\mathrm{I})}\right)$.

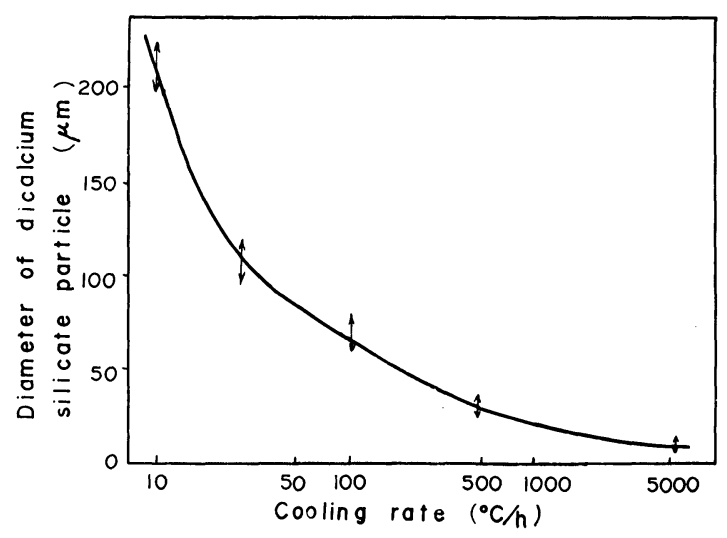

Fig. 7. Effect of cooling rate on the size of dicalcium silicate particle. of dicalcium silicate particles is affected by particle size. Accordingly, study was made on the relation between cooling rate and particle size. After remelting the slag (No. 11) completely by heating it in a magnesia crucible to $1600^{\circ} \mathrm{C}$, it was cooled from $1600^{\circ}$ to $1350^{\circ} \mathrm{C}$ at various cooling rates and was then quenched from $1350^{\circ} \mathrm{C}$. The particle sizes of such sample were measured, the results of which are shown in Fig. 7. The growth of particles is accelerated as the cooling rate decreases. At cooling rates below $0.1^{\circ} \mathrm{C} / \mathrm{min}$, the growth of particles up to 210 to $230 \mu \mathrm{m}$ was observed.

In case when the slag was teemed into a large mold of the size comparable with the one in practical use and cooled slowly, several large particles were combined into one to form particles of complex shape.

To study the time during which the slag can be maintained in the liquid state in the mold, the solidification rate of the slag teemed into the mold at $1600^{\circ} \mathrm{G}$ was measured by the liquid slag discharging method. As a result, $k=1$ was obtained for Eq. (7).

$$
D=k \sqrt{t}
$$

where, $D:$ thickness of solidified layer $(\mathrm{cm})$

$t$ : time after teeming (min)

$k$ : solidification constant $\left(\mathrm{cm} \cdot \mathrm{min}^{-1 / 2}\right)$

According to the calculation by Eq. (7), the time required for complete solidification of the slag teemed into a mold with a cross section of $800 \mathrm{~mm} \times 1100 \mathrm{~mm}$ is $26.7 \mathrm{hr}$.

To estimate the cooling rate necessary for separation of dicalcium silicate phase, the separating condition of $\mathrm{P}_{2} \mathrm{O}_{5}$ in the cross section at a position $20 \%$ up from the bottom was examined, the results of which are shown in Fig. 8. The axis of abscissa represents

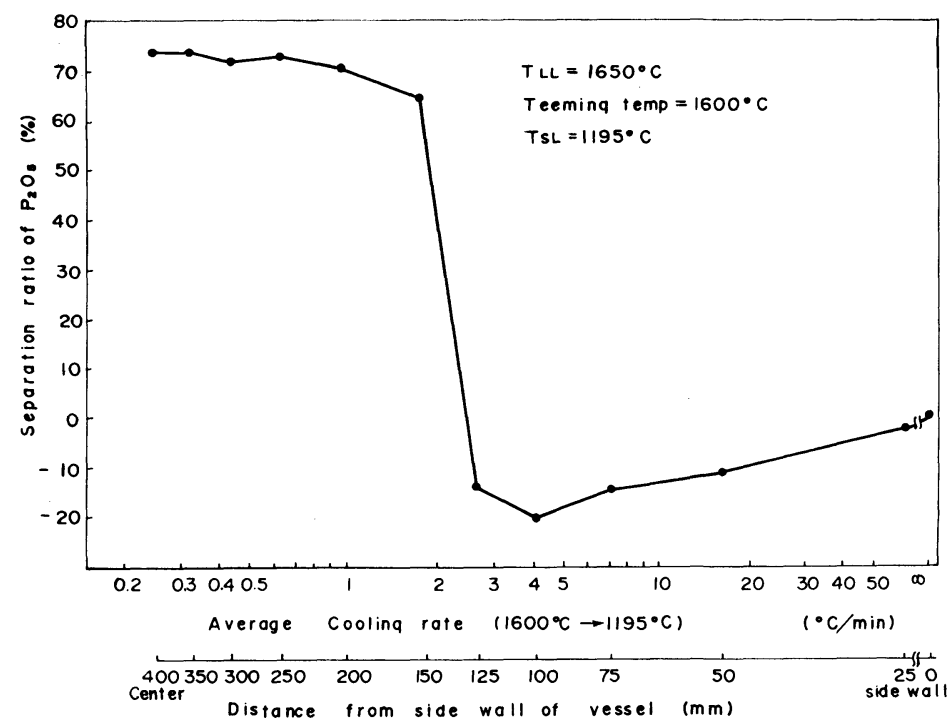

The cooling rate was calculated on the basis of temperature difference (between teeming temp. and solidus temp.) and solidification time.

$T_{L L}$ and $T_{S L}$ are liquidus temperature and solidus temperature, respectively.

Fig. 8. Effect of average cooling rate on separation ratio of $\mathrm{P}_{2} \mathrm{O}_{5}$. 
the distance from the surface to the center. In this figure, the apparent cooling rate is also shown. This apparent cooling rate was calculated by dividing the difference between teeming temperature and solidus temperature determined from the phase diagram by the time required for solidification at each position as calculated by Eq. (7). As described later, the cooling rate in the temperature range from $1600^{\circ}$ to $1450^{\circ} \mathrm{C}$ at which separation is considered to take place will be far smaller because of the small heat transfer rate of slag. It will be seen from Fig. 8 that separation is done effectively at a cooling rate below $2.0^{\circ} \mathrm{C} / \mathrm{min}$.

(4) Effect of Blowing Oxygen on the Modification of Slag

With a view to raising slag temperature and decreasing the melting point of slag, experiment on the modification of sligg by blowing oxygen was conducted.

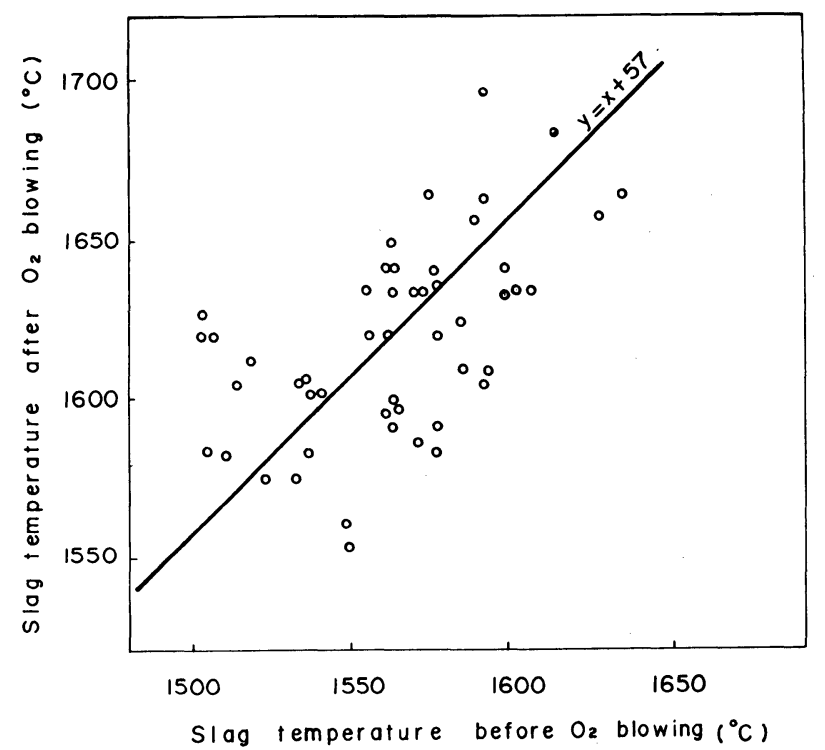

Oxygen was injected into liquid slag held in a covered slag pan.

Fig. 9. Influence of oxygen blowing on slag temperature.

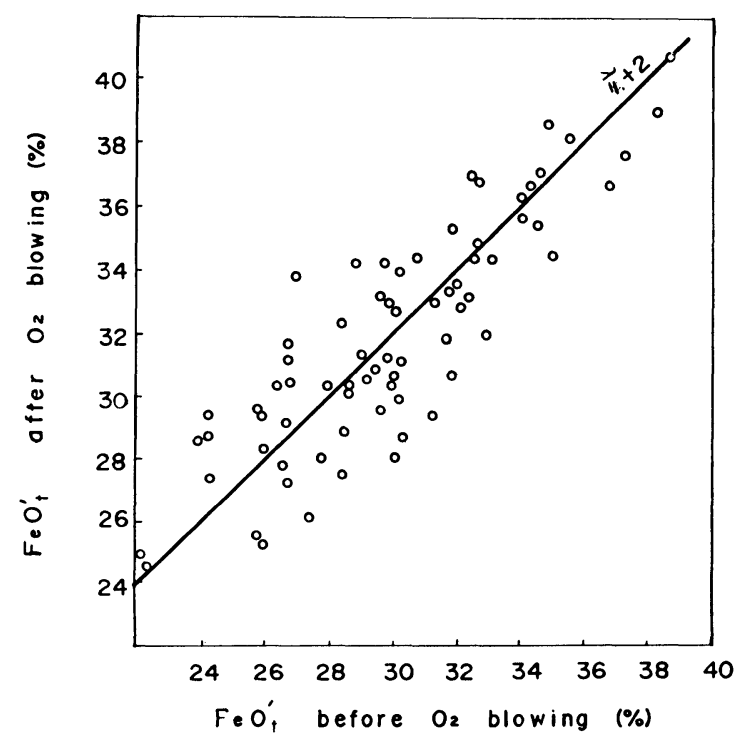

Fig. 10. Effect of oxygen blowing on $\mathrm{FeO}_{\mathrm{t}}^{\prime}$ content.
After placing about $12 \mathrm{t}$ of slag in a slag pan made of cast iron and covering it, oxygen was blown into the liquid slag using a calorized steel pipe. The results of oxygen blowing are shown in Figs. 9 to 11 . Figure 12 shows the results of solidification of modified slag teemed into a mold with a cross section of $800 \mathrm{~mm}$ $\times 1100 \mathrm{~mm}$.

In this experiment, the temperature rise of slag was $57^{\circ} \mathrm{C}$ on the average. As changes in the amount of suspended iron drops and $\% \mathrm{FeO} / \% \mathrm{Fe}_{2} \mathrm{O}_{3}$ were observed before and after oxygen blowing, it is considered that the above-mentioned temperature rise is attributed to the oxidation of iron drops and $\mathrm{FeO}$. As the rate of temperature rise is affected by oxygen blowing or heat insulating condition, it is essential to set these conditions so as to obtain a high temperature rise.

For LD converter slag in which the ratio of $\mathrm{CaO}$ to $\mathrm{SiO}_{2}$ is 3 , the comparison of the $\mathrm{CaO}-\mathrm{SiO}_{2}-\mathrm{FeO}$ phase diagram with the $\mathrm{CaO}-\mathrm{SiO}_{2}-\mathrm{Fe}_{2} \mathrm{O}_{3}$ phase diagram reveals a decrease of liquidus temperature

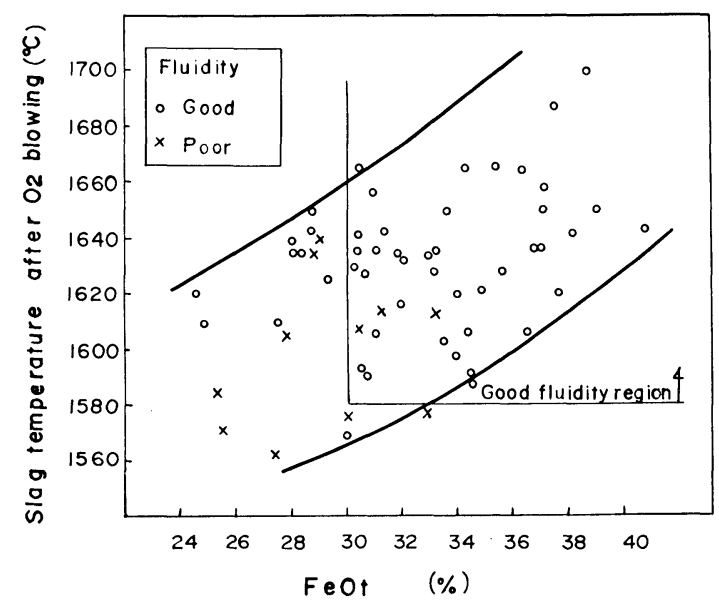

Fig. 11. Influence of $\mathrm{FeO}_{\mathrm{t}}^{\prime}$ content in slag and temperature on good fluidity region.

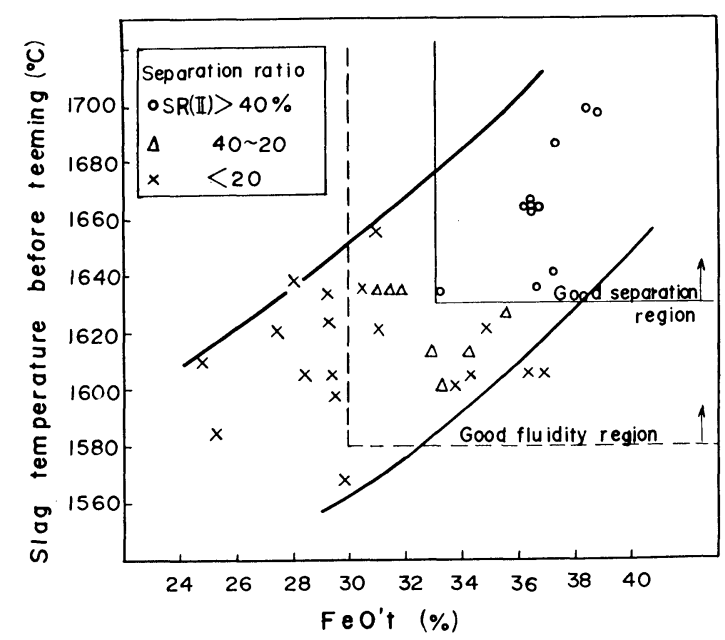

$\mathrm{SR}_{(\mathrm{II})}=\frac{\% \mathrm{P}_{2} \mathrm{O}_{5} \text { (av.) }-\% \mathrm{P}_{2} \mathrm{O}_{5} \text { (av. of Bottom) }}{\% \mathrm{P}_{2} \mathrm{O}_{5} \text { (av.) }} \times 100(\%)$

Fig. 12. Influence of $\mathrm{FeO}_{\mathrm{t}}^{\prime}$ content in slag and temperature before teeming on good separation region. Average temperature drop during teeming was $80^{\circ} \mathrm{C}$. 
even if $\mathrm{T} \cdot \mathrm{Fe}(\%)$ (iron content in $\mathrm{FeO}+\mathrm{Fe}_{2} \mathrm{O}_{3}$ ) is the same. Accordingly, the melting point of slag is expected to decrease when $\mathrm{Fe}_{2} \mathrm{O}_{3}$ is increased by oxygen blowing. When iron drops are oxidized, $\mathrm{FeO}_{\mathrm{t}}^{\prime}$ is increased, resulting in a decrease of melting point.

It is apparent from Fig. 11 that the fluidity of slag is dependent upon composition and temperature. To obtain slag A of good fluidity, it is necessary to increase $\mathrm{FeO}_{\mathrm{t}}^{\prime}$ to more than $30 \%$ and to raise slag temperature above $1580^{\circ} \mathrm{C}$.

When $\mathrm{FeO}_{\mathrm{t}}^{\prime}$ is higher than $33 \%$ and the temperature before teeming is higher than $1630^{\circ} \mathrm{C}, \mathrm{SR}_{(\text {II) }}$ is more than $40 \%$ as shown in Fig. 12. The reason why the composition and temperature region in which fluidity is good did not agree with the region in which the separating condition is good may be that a temperature drop of about $80^{\circ} \mathrm{C}$ on the average was caused during the teeming of liquid slag from the ladle into the mold.

\section{Separating Mechanism of Dicalcium Silicate Particles}

The separation of dicalcium silicate particles is a phenomenon in which particles in the liquid float up and condense in the temperature range from the start to the end of crystallization. If Stewart's theory on slurry settling ${ }^{15)}$ is applied to the floatation of such particles, the floating condition of particles will vary with the density of slurry, i.e., the amount of crystallization of dicalcium silicate particles. This floating condition is classified into four types as described below.

(a) When slurry density is lowest (free floatation)

Particles or flocks float up without being affected by other particles and do not form a clear boundary surface. The floating speed is dependent on the size and density of particles or flocks and the physical properties of liquid.

(b) When the density is intermediate (phase floatation)

Collective floatation occurs in the top layer, while free floatation takes place in the bottom layer. The boundary surface is not clear.

(c) In the case of heavy slurry (collective floatation)

A clear boundary surface is formed. The floating speed decreased with density. Floatation is obstructed by interference among particles.

(d) When the density is highest (consolidation)

Particles or flocks come into close contact with each other. The slurry in the upper part is consolidated by the floating force of particles which accumulated in the lower part.

The amount of crystallization of dicalcium silicate particles varies with the composition and temperature of slag but is increased by cooling in the range of crystallization temperature. The liquidus temperature of LD converter slag of good fluidity ranges from $1550^{\circ}$ to $1750^{\circ} \mathrm{C}$ depending on its composition. The case in which the liquidus temperature is $1650^{\circ} \mathrm{C}$ will be studied hereinbelow. Assuming a slow cooling condition in which the cooling rate is very low, the relation between temperature and the amount of crystallization of particles in the slag of typical com- position was determined from the phase diagram. Figure 13 shows this relation in terms of equilibrium volume ratio. Except directly under the liquidus line, the equilibrium volume ratio $l-\varepsilon(\varepsilon$ is the volume ocuupied by the liquid in the unit volume of slurry) ranges from 0.1 to 0.5 . It is considered that the density of dicalcium silicate particles is in the range between the intermediate range and the heavy slurry range. As the slag temperature drops, phase floatation is changed to collective floatation.

In this paragraph, therefore, the floating speed under phase and collective floatation will be studied. However, as numerical values necessary for calculation cannot be obtained with high accuracy, the following assumptions were used to simplify calculation.

(1) The size of crystal is expressed as a function of temperature, fixing the cooling rate at $1^{\circ} \mathrm{C} / \mathrm{min}$.

(2) It is assumed that all particles float up singly. Coagulative floatation due to the combination of coarsened particles is not taken into consideration.

(3) The floating speed should be the absolute floating speed but not the relative speed in which the change of position between liquid and solid is taken into consideration.

The floating speed of dicalcium silicate particles decreases with increasing amount of their crystallization. The relation between slurry density and floating speed varies in a complex manner with the shape, size, density and coagulating condition of particles and the physical properties of liquid. Generally, this relation must be determined through measurement. According to the explanation by Yoshida et al.,16) however, the floating speed decreases with increasing density for the following reasons.

(i) The difference of density which is the motive power of floatation decreases from $\left(\rho_{l}-\rho_{s}\right)$ to $\left(\rho^{\prime}-\rho_{s}\right)$ ( $\rho^{\prime}$ is the apparent density of slurry which is related to floating separation).

(ii) The viscosity increases from the viscosity of liquid alone to the apparent viscosity of slurry.

(iii) When the particle density increases, the absolute floating speed of particles becomes smaller than the relative speed between particle and liquid.

Accordingly, the relation among the respective

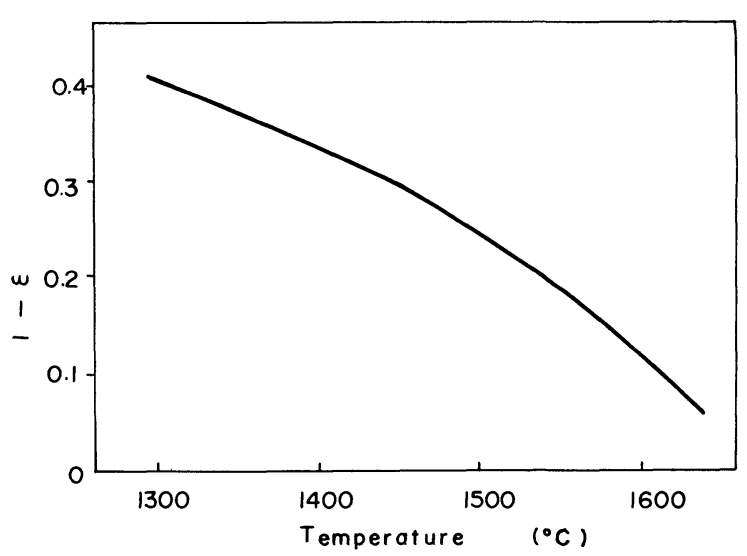

Fig. 13. Equilibrium volume ratio of dicalcium silicate particles crystallized at various temperatures. 
factors and particle density should be made clear. Applying Steinour's experimental equation on slurry, ${ }^{17)}$ the floating speed of dicalcium silicate particle groups can be expressed as follows:

$$
\begin{aligned}
& R=g\left(\rho_{l}-\rho_{s}\right) \cdot D^{2} \cdot \varepsilon^{2} \phi(\varepsilon) / 18 \mu \\
& \quad=U_{\mathrm{St}} \cdot \varepsilon^{2} \phi(\varepsilon) \\
& U_{\mathrm{St}} \cdot \varepsilon^{2} \cdot 10^{-1.82(1-\varepsilon)} \quad \ldots \ldots \ldots \ldots
\end{aligned}
$$

where, $R:$ floating speed of particle groups

$U_{\mathrm{St}}$ : free floating speed according to Stokes' equation

$\rho_{l}$ : density of liquid at $1500^{\circ} \mathrm{C}$ which is 3.14 according to the calculation by Yavoysky's equation ${ }^{8)}$

Changes of $\rho_{l}$ with temperature were neglected as they were as small as $\pm 2.2 \%$.

$\rho_{s}$ : Density of dicalcium silicate particles at $1500^{\circ} \mathrm{C}$

$\rho_{s}$ was taken at 2.75 by extrapolation of the value at normal temperature according to Spencer, ${ }^{19)}$ which is 2.93 , up to $1500^{\circ} \mathrm{G}$ on the basis of the results of measurement of linear expansion coefficient by Krikorian. ${ }^{20}$ Changes of $\rho_{s}$ with temperature were neglected as they were as small as $\pm 0.45 \%$.

$D$ : Particle diameter

Samples were prepared by cooling the liquid slag at a rate of $1^{\circ} \mathrm{C} / \mathrm{min}$ and quenching them from various experimental temperatures.

The particle sizes obtained from such samples were approximated by the following equation as a function of temperature, the results of which are shown in Fig. 14.

$$
D^{\prime}=96.50-\frac{207.0}{\pi} \arctan \left(\frac{T-1552.5}{12.53}\right)
$$

where, $D^{\prime}: \quad$ diameter of particle $(\mu \mathrm{m}), D=D^{\prime} \times 10^{-6}$ (m)

$T$ : slag temperature $\left({ }^{\circ} \mathrm{C}\right), 1300 \leqq T \leqq 1600$

$\mu$ : coefficient of viscosity

The viscosity of slag A shown in Fig. 2 was approximated by the following equation.

$$
\mu=2.3136 \cos h\left(\frac{T-1600}{24.9}\right)
$$

where, $\mu:$ coefficient of viscosity $(\mathrm{kg} / \mathrm{m} \cdot \mathrm{min})$

T: $\quad$ slag temperature $\left({ }^{\circ} \mathrm{C}\right), 1400 \leqq T \leqq 1600$

$\varepsilon$ : volume occupied by liquid in the unit volume of slurry

$\phi(\varepsilon)$ : correction factor for percentage of voids which is a function of $\varepsilon$ alone

According to Steinour, $\phi(\varepsilon)=10^{-1.82(1-\varepsilon)}$ is given for various spherical particles when $\varepsilon$ is 0.5 to 1.0 .

Assuming that dicalcium silicate particles are in the collective floating state at all temperatures from the start of cooling to the end of crystallization, the floating speed and floating distance at various temperatures were calculated using Eq. (9), the results of which are shown in Figs. 15 and 16.

Based on Fig. 15, it is estimated that the separation of dicalcium silicate particles is mostly effected in a narrow temperature range with $1540^{\circ} \mathrm{C}$ as the central value. For effective separation of particles, therefore, it is necessary to cool the slag at a cooling rate below

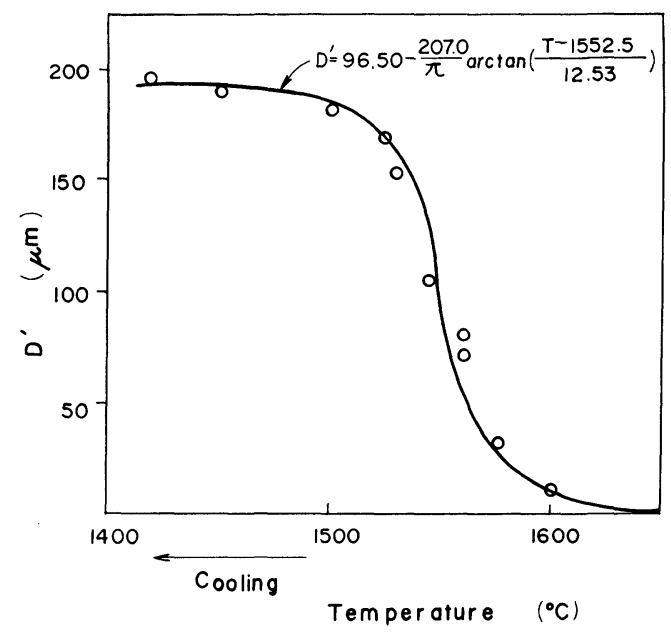

$D^{\prime}:$ the diameter of dicalcium silicate particle which was approximated by experimental equation,

Fig. 14. Relation between temperature and $D^{\prime}$ at cooling rate of $1^{\circ} \mathrm{G} / \mathrm{min}$.

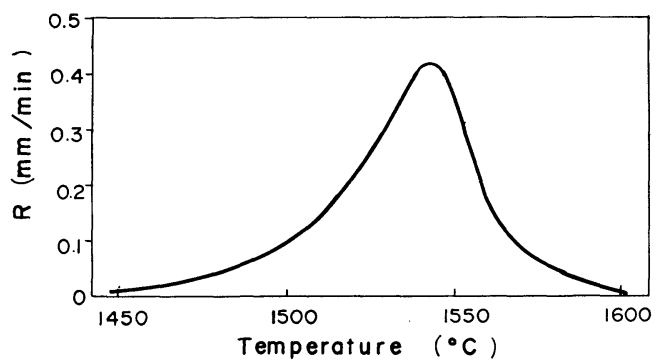

Fig. 15. Relation between slag temperature and floating speed $(R)$ of dicalcium silicate particle in the state of collective floatation.

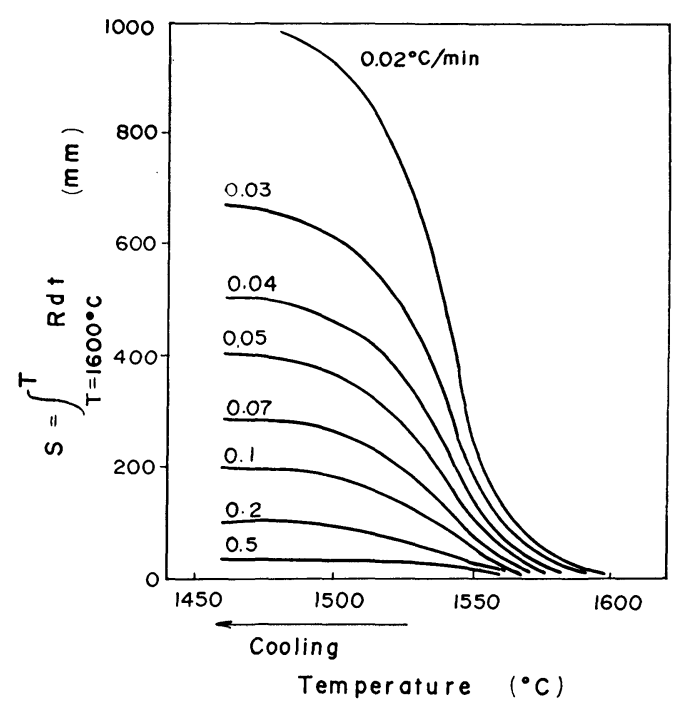

Fig. 16. Relation between slag cooling temperature and floating distance (S) calculated at various cooling rates. 
$2.0^{\circ} \mathrm{C} / \mathrm{min}$ within the above-mentioned temperature range.

The calculated values shown in Fig. 16 are smaller than the values to be encountered in practice because of the effects of assumptions used for calculation.

\section{Conclusions}

As a method for recovery of useful components, such as $\mathrm{FeO}, \mathrm{MnO}$ and $\mathrm{CaO}$, by separating $\mathrm{P}_{2} \mathrm{O}_{5}$ from slag through condensation, a method in which dicalcium silicate particles with solute $\mathrm{P}_{2} \mathrm{O}_{5}$, which is primarily crystallized during cooling of liquid slag, are separated by floatation has been developed and the effects of various factors on dephosphorization ratio were examined.

(1) Effect of starting temperature of cooling

The dephosphorization ratio increases as the starting temperature of cooling rises. To obtain $\mathrm{SR}_{\text {(II) }}$ higher than $40 \%$ for slag $\mathrm{A}$, the starting temperature of cooling must be higher than $1580^{\circ} \mathrm{C}$ for the following reason. Namely, as the calculated range of separating temperature for slag $\mathrm{A}$ with a melting point of $1650^{\circ} \mathrm{C}$ is $1570^{\circ}$ to $1480^{\circ} \mathrm{C}$, the effect of slow cooling from a comparatively high temperature in the solid-liquid coexisting region is great.

(2) Effect of composition

In practical operation, slow cooling in the mold is started from about $1600^{\circ} \mathrm{C}$. When the starting temperature of slow cooling is fixed, the starting temperature of crystallization must be as low as possible to effect slow cooling down to the separating temperature, and the amount of $\mathrm{FeO}_{\mathrm{t}}^{\prime}$ must be higher than $30 \%$ to obtain $\mathrm{SR}_{(\mathrm{II})}$ higher than $40 \%$.

(3) Effect of cooling rate

For floating separation of dicalcium silicate particles, slow cooling from $1600^{\circ}$ to $1450^{\circ} \mathrm{C}$ at an average cooling rate of less than about $2.0^{\circ} \mathrm{C} / \mathrm{min}$ is necessary. Assuming a collective floatation model of single particles, the floating speed of dicalcium silicate was calculated. Based on this speed, the separating temperature range was calculated to be $1570^{\circ}$ to $1480^{\circ} \mathrm{C}$ (when the liquidus temperature is $1650^{\circ} \mathrm{C}$ ). Although this floating speed is lower than that in practice, further studies should be made in consideration of the coarsening of quasiparticles due to the combination of particles, change of position between solid and liquid due to settling of residual liquid, the dependence of particle size on cooling rate, etc.

\section{Acknowledgements}

The authors wish to express their gratitude to Messrs. Hiromi Fukuoka and Kinji Kanematsu, Refractories Development Office, Heat Control Dept., Nippon Steel Corp, for their cooperation in the measurement of slag viscosity, also to Prof. Kazumi Ogino, Dept. of Technology, Osaka University, and Prof. Yoshikazu Takahashi and Assist. Prof. Hideaki Suito, Research Institute of Mineral Dressing and Metallurgy, Tohoku University, for their valuable advice.

\section{REFERENGES}

1) Authors: not published.

2) H. Suito, Y. Hayashida and Y. Takahashi: Tetsu-to-Hagané, 63 (1977), 1252.

3) K. Ogino: Private letter.

4) T. Fujimoto: Private letter.

5) S. Usui: Private letter.

6) W. Oelsen and H. Maetz: Mitteilung Kaiser-Wilherm Inst. Eisenforschung, Band XXIII, Düsseldorf, (1941), 495.

7) S. Shiomi, N. Sano and Y. Matsushita: Tetsu-to-Hagané, 63 (1977), 1520.

8) H. Fukuoka, K. Kanematsu, M. Sasaki and T. Enokido: Tetsu-to-Hagané, 65 (1979), S138 and private letter.

9) E. M. Levin, C. R. Robbins and H. F. McMurdie: Phase Diagrams for Ceramists, Amer. Ceram. Soc., (1964), 228.

10) K. Narita, T. Onoue and N. Takada: Report of the 19th Comm. (Steelmaking) of Japan Soc. for the Promotion of Science, (1977), No. 10014.

11) R. W. Nurse, J. H. Welch and W. Gutt: J. Chem. Soc., 220 (1959), 1077.

12) R. L. Barrett and W. J. McGaughey: Amer. Mineralogist, 27 (1942), 680.

13) G. Trömel: Stahl u. Eisen, 63 (1943), 21.

14) S. Zerfoss and H. M. Davis: J. Amer. Ceram. Soc., 26 (1943), 302.

15) R. E. Stewart: Chemical Engineering Practice, III, Solid Systems, Butterworths, London, (1957), 248.

16) F. Yoshida and Y. Mori: Chemical Engineering in Detail, I, Asakura-shoten, Tokyo, (1969), 329.

17) H. H. Steinour: Ind. Eng. Chem., 36 (1944), 618 and 840.

18) V.I. Yavoysky: Theory of Steel Refining Process, Japan Soc. for the Promotion of Science, (1971), 68.

19) O.R.F. Spencer and D. S. Coleman: Trans. of Brit. Ceram. Soc., 68 (1969), 125.

20) D. H. Krikorian: "Thermophysical Properties of Matter", The TPRG Data Series, Report No. UCRL-6132, (1960). 